Ind. Health, 1974, 12, 127.

\title{
CLINICO-CHEMICAL STUDIES ON SUBACUTE CADMIUM POISONING IN RABBITS
}

\author{
Hiroshi YOSHIKAWA, Motoyasu OHSAWA \\ and Masami KANETA
}

\author{
Vational Institute of Industrial Health, Kisuki-sumiyoshi, Nakahara-ku, Kawasaki \\ and Graduate School, Faculty of Hygienic Sciences, \\ Kitazato University, Asamizodai, Sagamihara
}

(Received July 30, 1974)

GOT, GPT, LDH, total Ac-P, prostatic Ac-P, Al-P, cholesterol, free fatty acid, $\mathrm{Ca}$, and $\mathrm{P}$ in plasma were measured once a week on rabbits injected subcutaneously with 0.5 and $1.0 \mathrm{mg} \mathrm{Cd} / \mathrm{kg}$ daily for 11 weeks respectively, and $\mathrm{Cd}, \mathrm{Cu}, \mathrm{Mn}$, and $\mathrm{Zn}$ contents in organs were determined at the termination of the experiment.

Prostatic Ac-P activity, cholesterol, and free fatty acid levels in plasma rose in the early stage of administration, and GOT, GPT, LDH, and Al-P activities rose in the latter stage of administration. Ca and $P$ levels in plasma did not change in all periods of the experiment. From these results, it could be concluded that a measurement of prostatic Ac-P, cholesterol, and free fatty acid is available for knowing an excess intake of $\mathrm{Cd}$.

Cd contents in heart, lungs, spleen, and testes of rabbits injected with $1.0 \mathrm{mg}$ $\mathrm{Cd} / \mathrm{kg}$ increased significantly compared with those with $0.5 \mathrm{mg} \mathrm{Cd} / \mathrm{kg}$, but a difference between the two groups in $\mathrm{Cd}$ contents in liver, kidneys and submandibular glands which contained high concentration of $\mathrm{Cd}$ was not recognized. Zn contents in organs of rabbits injected with $\mathrm{Cd}$ increased remarkably, while $\mathrm{Cu}$ contents decreased generally. This phenomenon was especially remarkable in liver and kidneys.

Main injuries caused by $\mathrm{Cd}$ poisoning in industry are lung emphysema ${ }^{1 \sim 4)}$ and renal damage $^{5 \sim 8)}$ with proteinuria including low-molecular-weight-proteins. Moreover, anemia, bone injury, and nephrolothiasis ${ }^{9)}$ have been reported. At present, study of Cd poisoning has mainly laid emphasis on low-molecular-weight-proteins in urine and its mechaism of excretion. However, neither urinary excretion of these proteins caused by an exposure to $\mathrm{Cd}$ is not always related to the degree or period of exposure to $\mathrm{Cd}$ nor excretion of low-molecular-weight-protein indicates the degree of renal damage as progressing uremia. Epidmeniological evidence in man has implicated $\mathrm{Cd}$ in the etiology of hypertension $^{10,11)}$ and cardiovascular disease ${ }^{12)}$.

It would, therefore, be necessary to study from the larger viewpoint for evaluation of health effects caused by $\mathrm{Cd}$. The authors investigated the change of some enzyme activities, lipids, inorganic substances in plasma of rabbits injected daily with $\mathrm{Cd}$, and 


\section{H. YOSHIKAWA, M. OHSAWA AND M. KANETA}

also determined the contents of $\mathrm{Cu}, \mathrm{Mn}$, and $\mathrm{Zn}$ in organs to investigate the effect of $\mathrm{Cd}$ on essential metals.

\section{Materials AND Methods}

Twelve male Japanese white rabbit (about $3 \mathrm{~kg}$ of body weight) were divided into 3 groups. The first and second groups of animals were given subcutaeous injection of $\mathrm{CdCl}_{2}$ corresponding to $0.5 \mathrm{mg} \mathrm{Cd} / \mathrm{kg}$ (Group I) and $1.0 \mathrm{mg} \mathrm{Cd} / \mathrm{kg}$ (Group II) of body weight daily, five days a week (Monday to Friday) for 11 weeks. The third group was injected subcutaneously with the corresponding volume of distilled water as control.

Body weight was measured daily on all rabbits, and blood samples $(5 \mathrm{ml})$ were collected in every Monday morning by heart puncture before the injection. The blood samples were centrifuged at 3000 r.p.m. for $20 \mathrm{~min}$, and plasma were obtained. Of these plasma, the glutamic oxaloacetic transaminase (GOT) and glutamic pyruvic transaminase (GPT) were measured by the method of Reitman-Frankel, ${ }^{13)}$ alkaline phosphatase (Al-P) and acid phosphatase (total Ac-P and prostatic Ac-P) by the p-nitrophenyl phosphate method, ${ }^{14)}$ lactic dehydrogenase $(\mathrm{LDH})$ by the method of Wroblewski, ${ }^{16)}$ cholesterol by the method of Zak-Henly, ${ }^{16)}$ free fatty acid by the method of Novak, ${ }^{17)}$ calcium by the method of Connerty, ${ }^{18)}$ and phosphorous by the method of Tannssky, ${ }^{19}$ respectively.

At the end of the experiment, after $10 \mathrm{ml}$ of blood samples were collected from rabbits by heart puncture, all animals were killed by the technique of air embolism and their heart, lungs, liver, spleen, kidneys, adrenals, testes and submandibular glands were removed for determining their contents of metals. Red blood cells and plasma fractions obtained from the blood sample by centrifugation were analysed for $\mathrm{Cd}, \mathrm{Cu}$, $\mathrm{Mn}$, and $\mathrm{Zn}$ by the use of atomic absorption spectrophotometer (Hitachi Model 207), after digested with concentrated nitric acid and hydrogen peroxide.

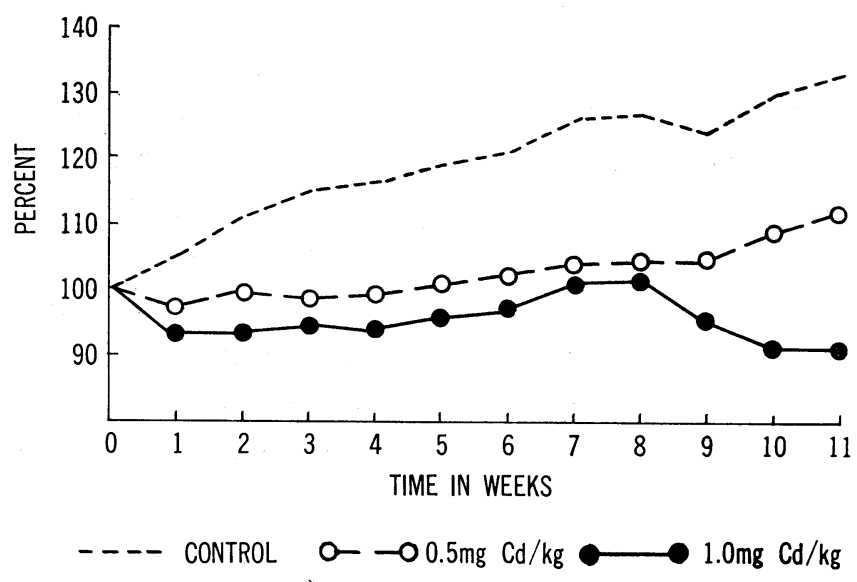

Eiig. 1. Curves for body weight of rabbits injected daily with cadmium. 


\section{CLINICO-CHEMICAL STUDY OF CADMIUM POISONING}

Table 1. Biochemical analysis of plasma.

\begin{tabular}{|c|c|c|c|c|c|c|}
\hline \multirow{2}{*}{ Week } & \multicolumn{3}{|c|}{$\begin{array}{c}\text { Glutamic oxaloacetic transaminase } \\
\text { (Karmen unit) }\end{array}$} & \multicolumn{3}{|c|}{$\begin{array}{l}\text { Glutamic pyruvic transaminase } \\
\text { (Karmen unit) }\end{array}$} \\
\hline & $1.0 \mathrm{mg} / \mathrm{kg}$ & $0.5 \mathrm{mg} / \mathrm{kg}$ & Controls & $1.0 \mathrm{mg} / \mathrm{kg}$ & $0.5 \mathrm{mg} / \mathrm{kg}$ & Controls \\
\hline 0 & $27.3 \pm 6.5$ & $22.5 \pm 6.3$ & $26.2 \pm 7.3$ & $22.5 \pm 10.7$ & $18.5 \pm 6.1$ & $28.4 \pm 7.6$ \\
\hline 1 & $32.5 \pm 9.3$ & $24.9 \pm 9.4$ & $21.1 \pm 2.0$ & $30.6 \pm 6.8$ & $25.4 \pm 5.5$ & $30.1 \pm 7.3$ \\
\hline 2 & $36.8 \pm 3.8$ & $21.0 \pm 3.2$ & $24.7 \pm 5.2$ & $37.2 \pm 7.1$ & $18.7 \pm 3.4$ & $24.6 \pm 5.6$ \\
\hline 3 & $28.3 \pm 6.4$ & $21.1 \pm 7.5$ & $22.5 \pm 2.3$ & $29.3 \pm 7.7$ & $20.0 \pm 5.8$ & $23.6 \pm 5.6$ \\
\hline 4 & $29.6 \pm 10.6$ & $17.5 \pm 5.5$ & $21.6 \pm 3.9$ & $31.5 \pm 8.2$ & $17.8 \pm 3.7$ & $27.1 \pm 7.3$ \\
\hline 5 & $27.7 \pm \quad 4.4$ & $23.2 \pm 9.9$ & $31.9 \pm 5.5$ & $36.9 \pm 6.5$ & $21.4 \pm 7.0$ & $28.9 \pm 5.1$ \\
\hline 6 & $29.5 \pm 12.9$ & $27.4 \pm 14.5$ & $20.8 \pm 6.4$ & $40.5 \pm 9.4$ & $24.9 \pm 10.2$ & $24.3 \pm 7.0$ \\
\hline 7 & $30.9 \pm \quad 5.8$ & $38.2 \pm 17.1$ & $25.4 \pm 7.3$ & $31.7 \pm 7.9$ & $27.5 \pm 12.7$ & $25.5 \pm 5.6$ \\
\hline 8 & $39.6 \pm 24.3$ & $37.1 \pm 34.4$ & $21.8 \pm 3.8$ & $36.9 \pm 16.6$ & $25.0 \pm 15.3$ & $23.6 \pm 11.1$ \\
\hline 9 & $144.4 \pm 116.9$ & $42.1 \pm 23.1$ & $23.9 \pm 8.5$ & $117.1 \pm 92.4$ & $37.7 \pm 22.0$ & $30.4 \pm 10.9$ \\
\hline 10 & $198.3 \pm 94.9$ & $43.6 \pm 29.4$ & $24.7 \pm 2.9$ & $139.7 \pm 38.9$ & $29.0 \pm 22.3$ & $24.1 \pm 9.0$ \\
\hline 11 & $102 \pm 0 \pm 53.3$ & $40.1 \pm 26.9$ & $26.6 \pm 5.2$ & $129.2 \pm 89.4$ & $27.0 \pm 15.7$ & $24.4 \pm 10.8$ \\
\hline
\end{tabular}

Table 1. (Continued)

\begin{tabular}{c|ccc|ccc}
\hline \multirow{2}{*}{ Week } & \multicolumn{3}{|c|}{$\begin{array}{c}\text { Alkaline phoshatase } \\
\text { (Bessey-Lowry unit) }\end{array}$} & \multicolumn{3}{c}{$\begin{array}{c}\text { Lactic dehydrogenase } \\
\text { (Wroblewski unit) }\end{array}$} \\
& $1.0 \mathrm{mg} / \mathrm{kg}$ & $0.5 \mathrm{mg} / \mathrm{kg}$ & Controls & $1.0 \mathrm{mg} / \mathrm{kg}$ & $0.5 \mathrm{mg} / \mathrm{kg}$ & Controls \\
\hline 0 & $2.6 \pm 0.98$ & $2.5 \pm 0.61$ & $2.7 \pm 0.42$ & $212 \pm 58.7$ & $204 \pm 39.4$ & $210 \pm 47.5$ \\
1 & $1.3 \pm 0.78$ & $0.8 \pm 0.19$ & $2.5 \pm 0.10$ & $220 \pm 51.3$ & $206 \pm 45.2$ & $198 \pm 49.1$ \\
2 & $1.8 \pm 0.29$ & $1.3 \pm 0.98$ & $2.0 \pm 0.39$ & $481 * \pm 76.0$ & $258 \pm 32.0$ & $250 \pm 32.4$ \\
3 & $1.6 \pm 0.52$ & $1.2 \pm 0.41$ & $2.4 \pm 0.29$ & $260 \pm 19.7$ & $252 \pm 23.7$ & $222 \pm 52.4$ \\
4 & $2.1 \pm 0.59$ & $0.9 \pm 0.37$ & $2.1 \pm 0.30$ & $225 \pm 101.4$ & $229 \pm 45.4$ & $198 \pm 22.7$ \\
5 & $1.9 \pm 0.76$ & $1.0 \pm 0.24$ & $1.9 \pm 0.41$ & $242 \pm 18.1$ & $195 \pm 17.1$ & $260 \pm 62.3$ \\
6 & $1.8 \pm 0.86$ & $0.9 \pm 0.22$ & $1.6 \pm 0.54$ & $238 \pm 54.2$ & $216 \pm 63.8$ & $199 \pm 45.7$ \\
7 & $1.7 \pm 0.41$ & $1.1 \pm 0.27$ & $1.5 \pm 0.41$ & $263 \pm 54.1$ & $207 \pm 18.8$ & $187 \pm 13.7$ \\
8 & $1.6 \pm 0.36$ & $0.9 \pm 0.36$ & $1.3 \pm 0.33$ & $341 \pm 155.9$ & $217 \pm 30.9$ & $181 \pm 33.5$ \\
9 & $4.5 \pm 3.05$ & $1.3 \pm 0.65$ & $1.1 \pm 0.18$ & $301 \pm 85.7$ & $174 \pm 43.3$ & $237 \pm 45.3$ \\
10 & $5.8 \pm 3.41$ & $1.3 \pm 0.41$ & $1.6 \pm 0.52$ & $585 \pm 191.5$ & $287 \pm 33.0$ & $260 \pm 16.1$ \\
11 & $4.8 \pm 2.66$ & $1.0 \pm 0.38$ & $1.1 \pm 0.21$ & $481 \pm 148.9$ & $207 \pm 60.2$ & $176 \pm 30.9$ \\
\hline
\end{tabular}

*: Plasma from hemolytic blood.

\section{RESUlts}

\section{Changes of body weight and general appearance}

The lapses of average body weight in each group at every week for 11 weeks are shown in Fig. 1. This figure presents percentages of body weight of animals after injection to that before injection. In the two groups of $\mathrm{Cd}$ injected animals body weight did not increase for 4 weeks after the first injection. In the Group I, body weight increased gradually after the 5th week. Rabbits in this group gave no abnormal sign throughout the period of the experiment. In the Group II, body weight increased during 


\section{H. YOSHIKAWA, M. OHSAWA AND M. KANEDA}

Table 1. (Continued)

\begin{tabular}{c|rrr|rrr}
\hline \multirow{2}{*}{ Week } & \multicolumn{3}{|c|}{$\begin{array}{c}\text { Prostatic acid phosphatase } \\
\text { (Bessey-Lowry unit) }\end{array}$} & \multicolumn{3}{c}{$\begin{array}{c}\text { Total acid phosphatase } \\
\text { (Bessey-Lowry unit) }\end{array}$} \\
& $1.0 \mathrm{mg} / \mathrm{kg}$ & $0.5 \mathrm{mg} / \mathrm{kg}$ & Controls & $1.0 \mathrm{mg} / \mathrm{kg}$ & $0.5 \mathrm{mg} / \mathrm{kg}$ & Controls \\
\hline 0 & $0.64 \pm 0.43$ & $0.47 \pm 0.39$ & $0.44 \pm 0.25$ & $7.1 \pm 0.95$ & $6.0 \pm 1.69$ & $7.8 \pm 0.71$ \\
1 & $0.92 \pm 0.68$ & $0.48 \pm 0.31$ & $0.53 \pm 0.19$ & $10.4 \pm 0.58$ & $9.5 \pm 1.76$ & $6.4 \pm 0.83$ \\
2 & $0.76 \pm 0.49$ & $0.55 \pm 0.24$ & $0.49 \pm 0.35$ & $8.8 \pm 3.09$ & $8.3 \pm 1.46$ & $5.8 \pm 0.77$ \\
3 & $1.13 \pm 0.78$ & $0.43 \pm 0.21$ & $0.40 \pm 0.06$ & $7.2 \pm 0.43$ & $5.3 \pm 0.55$ & $5.1 \pm 0.60$ \\
4 & $2.50 \pm 0.74$ & $0.47 \pm 0.20$ & $0.44 \pm 0.27$ & $8.3 \pm 0.39$ & $5.6 \pm 1.40$ & $5.9 \pm 1.18$ \\
5 & $3.44 \pm 0.94$ & $1.02 \pm 0.45$ & $0.39 \pm 0.21$ & $9.1 \pm 1.54$ & $5.7 \pm 1.04$ & $5.4 \pm 1.35$ \\
6 & $5.62 \pm 2.53$ & $1.15 \pm 0.78$ & $0.42 \pm 0.28$ & $12.1 \pm 3.17$ & $6.2 \pm 1.45$ & $5.2 \pm 1.85$ \\
7 & $4.70 \pm 2.01$ & $1.11 \pm 0.39$ & $0.42 \pm 0.16$ & $10.1 \pm 2.64$ & $5.9 \pm 1.65$ & $4.5 \pm 1.66$ \\
8 & $4.78 \pm 2.65$ & $1.05 \pm 0.17$ & $0.42 \pm 0.25$ & $10.2 \pm 3.77$ & $6.0 \pm 1.58$ & $4.5 \pm 1.82$ \\
9 & $4.71 \pm 2.56$ & $1.47 \pm 0.88$ & $0.25 \pm 0.14$ & $10.6 \pm 3.84$ & $6.6 \pm 1.89$ & $5.9 \pm 3.34$ \\
10 & $3.53 \pm 2.52$ & $1.52 \pm 0.82$ & $0.27 \pm 0.05$ & $10.1 \pm 3.83$ & $6.5 \pm 1.08$ & $3.6 \pm 0.30$ \\
11 & $3.44 \pm 0.55$ & $1.37 \pm 0.54$ & $0.37 \pm 0.16$ & $8.7 \pm 0.81$ & $5.9 \pm 1.02$ & $3.2 \pm 0.14$ \\
\hline
\end{tabular}

Table 1. (Continued)

\begin{tabular}{c|rcc|ccc}
\hline & \multicolumn{3}{|c|}{$\begin{array}{c}\text { Cholesterol } \\
(\mathrm{mg} / \mathrm{dl})\end{array}$} & \multicolumn{3}{|c}{$\begin{array}{c}\text { Free fatty acid } \\
(\mathrm{mEq} / \mathrm{l})\end{array}$} \\
Week & & & & & \\
& $1.0 \mathrm{mg} / \mathrm{kg}$ & $0.5 \mathrm{mg} / \mathrm{kg}$ & Controls & $1.0 \mathrm{mg} / \mathrm{kg}$ & $0.5 \mathrm{mg} / \mathrm{kg}$ & Controls \\
\hline 0 & $89.0 \pm 20.6$ & $94.7 \pm 37.9$ & $85.7 \pm 17.0$ & $0.090 \pm 0.030$ & $0.112 \pm 0.047$ & $0.122 \pm 0.040$ \\
1 & $142.1 \pm 39.9$ & $165.1 \pm 65.8$ & $75.0 \pm 22.3$ & $0.152 \pm 0.066$ & $0.124 \pm 0.022$ & $0.150 \pm 0.049$ \\
2 & $155.1 \pm 69.9$ & $193.6 \pm 60.3$ & $70.0 \pm 26.2$ & $0.147 \pm 0.064$ & $0.151 \pm 0.063$ & $0.097 \pm 0.042$ \\
3 & $182.2 \pm 57.1$ & $211.4 \pm 65.1$ & $73.9 \pm 21.3$ & $0.150 \pm 0.065$ & $0.173 \pm 0.024$ & $0.065 \pm 0.009$ \\
4 & $199.3 \pm 54.2$ & $199.2 \pm 60.4$ & $74.7 \pm 25.3$ & $0.157 \pm 0.088$ & $0.125 \pm 0.057$ & $0.081 \pm 0.028$ \\
5 & $213.8 \pm 72.3$ & $216.7 \pm 76.3$ & $77.6 \pm 4.8$ & $0.139 \pm 0.053$ & $0.149 \pm 0.042$ & $0.098 \pm 0.023$ \\
6 & $233.4 \pm 83.8$ & $237.3 \pm 86.5$ & $61.3 \pm 12.2$ & $0.130 \pm 0.059$ & $0.182 \pm 0.066$ & $0.123 \pm 0.030$ \\
7 & $220.0 \pm 80.6$ & $236.7 \pm 79.1$ & $61.5 \pm 21.6$ & $0.091 \pm 0.026$ & $0.129 \pm 0.030$ & $0.073 \pm 0.020$ \\
8 & $2213 . \pm 58.7$ & $235.6 \pm 71.4$ & $56.4 \pm 10.4$ & $0.135 \pm 0.020$ & $0.183 \pm 0.010$ & $0.130 \pm 0.037$ \\
9 & $308.5 \pm 28.6$ & $249.5 \pm 81.2$ & $61.0 \pm 27.8$ & $0.274 \pm 0.130$ & $0.149 \pm 0.009$ & $0.223 \pm 0.152$ \\
10 & $316.6 \pm 36.7$ & $228.5 \pm 90.9$ & $57.9 \pm 23.2$ & $0.129 \pm 0.056$ & $0.135 \pm 0.032$ & $0.145 \pm 0.061$ \\
11 & $287.4 \pm 73.9$ & $245.9 \pm 76.4$ & $60.8 \pm 18.7$ & $0.190 \pm 0.099$ & $0.076 \pm 0.022$ & $0.060 \pm 0.014$ \\
\hline
\end{tabular}

the 5 th to the 8 th weeks, thereafter decreased again, and general appearances of rabbit at this period grown worse and remarkably weakened.

\section{Biochemical analysis of plasma}

The values of GOT, GPT, LDH, Al-P, cholesterol, free fatty acid, Ca, and P in plasma at every week for 11 weeks are shown in Table 1 . Percentages of each value to value before $\mathrm{Cd}$ injection are shown in Figs. 2, 3, and 4.

Values in control group did not fluctuate significantly throughout the experimental periods except Al-P and total Ac-P activities which decreased gradually throughout the experimental periods. 


\section{CLINICO-CHEMICAL STUDY OF CADMIUM POISONING}

Table 1. (Continued)

\begin{tabular}{c|ccc|ccc}
\hline & \multicolumn{3}{|c}{$\begin{array}{c}\text { Calcium } \\
\text { Week }\end{array}$} & & \multicolumn{3}{|c}{$\begin{array}{c}\text { Phosporous } \\
\text { (mg/dl) }\end{array}$} \\
& $1.0 \mathrm{mg} / \mathrm{kg}$ & $0.5 \mathrm{mg} / \mathrm{kg}$ & Controls & $1.0 \mathrm{mg} / \mathrm{kg}$ & $0.5 \mathrm{mg} / \mathrm{kg}$ & Controls \\
\hline 0 & $17.9 \pm 1.08$ & $16.1 \pm 1.18$ & $15.8 \pm 1.43$ & $6.0 \pm 0.35$ & $5.9 \pm 0.24$ & $5.6 \pm 0.34$ \\
1 & $15.8 \pm 1.97$ & $16.8 \pm 0.26$ & $15.7 \pm 0.44$ & $4.5 \pm 0.49$ & $5.3 \pm 0.43$ & $5.4 \pm 0.28$ \\
2 & $13.2 \pm 0.78$ & $13.6 \pm 0.76$ & $12.9 \pm 0.92$ & $4.8 \pm 0.43$ & $5.2 \pm 0.69$ & $5.7 \pm 0.22$ \\
3 & $16.2 \pm 1.33$ & $17.8 \pm 0.64$ & $17.4 \pm 0.62$ & $5.5 \pm 0.39$ & $5.3 \pm 0.78$ & $5.5 \pm 0.20$ \\
4 & $14.7 \pm 1.52$ & $15.2 \pm 0.65$ & $15.3 \pm 1.18$ & $5.5 \pm 0.29$ & $5.3 \pm 0.41$ & $5.1 \pm 0.21$ \\
5 & $15.2 \pm 0.54$ & $15.0 \pm 0.68$ & $14.7 \pm 0.62$ & $5.1 \pm 0.44$ & $5.1 \pm 0.45$ & $5.3 \pm 0.37$ \\
6 & $16.7 \pm 2.11$ & $17.0 \pm 0.16$ & $16.7 \pm 1.28$ & $4.8 \pm 0.59$ & $5.2 \pm 0.42$ & $5.4 \pm 0.23$ \\
7 & $15.5 \pm 0.75$ & $15.1 \pm 0.96$ & $15.5 \pm 1.01$ & $4.6 \pm 0.31$ & $5.2 \pm 0.53$ & $5.3 \pm 0.23$ \\
8 & $14.2 \pm 0.80$ & $16.1 \pm 0.37$ & $14.9 \pm 0.49$ & $5.0 \pm 0.26$ & $4.6 \pm 0.28$ & $5.6 \pm 0.54$ \\
9 & $17.7 \pm 2.80$ & $18.8 \pm 1.20$ & $16.5 \pm 0.70$ & $5.7 \pm 0.53$ & $4.8 \pm 0.46$ & $5.3 \pm 0.62$ \\
10 & $14.5 \pm 1.12$ & $14.6 \pm 1.80$ & $14.9 \pm 0.76$ & $4.2 \pm 0.66$ & $4.8 \pm 0.19$ & $5.0 \pm 0.22$ \\
11 & $15.6 \pm 1.30$ & $14.3 \pm 0.52$ & $15.3 \pm 1.15$ & $5.0 \pm 2.49$ & $4.1 \pm 0.14$ & $4.0 \pm 0.26$ \\
\hline
\end{tabular}

$G O T, G P T, L D H$. As shown in Fig. 2, GOT, GPT, and LDH activities in the Group II were the same as those in the control group untill the 8th week, but after the 9th week, these activities were enhanced remarkably. No significant difference was observed in these activities between the Group I and the control group, though they were somewhat enhanced after the 9th week in the Group I.

Al-P. Al-P activity in the Group I was similar to that in control group as shown in Fig. 2. On the contrary, this activity in the Group II increased remarkably after the 9th week.

Total Ac-P. As shown in Fig. 3, total Ac-P activity descended gradually with the daily injection of distilled water in control group. On the other hand, it increased at the 1st week by the injection of $\mathrm{Cd}$, but turned back to a normal value after the 3rd week in the Group I and thereafter maintained that value. In the Group II, this activity turned back to a normal value after 3 weeks, thereafter it began to rise again. However, in total Ac-P activity a significant difference between $\mathrm{Cd}$-injected groups and the control group was shown because the control group descended gradually.

Prostatic Ac-P. As shown in Fig. 3, prostatic Ac-P activity in the Group II rose rapidly during the weeks from the 1 st to the 6 th, the activity at the 6 th week was 10 times or more as high as that before injection, and this high level was maintained after that. In the Group I, the activity did not change from a normal value for the first 4 weeks and thereafter it was kept lower.

Cholesterol. As shown in Fig. 3, cholesterol level in plasma rose already at the 1st week of $\mathrm{Cd}$ injection and gradually increased with $\mathrm{Cd}$ injection. But increase in cholesterol level was not different between the two $\mathrm{Cd}$ injected groups. 

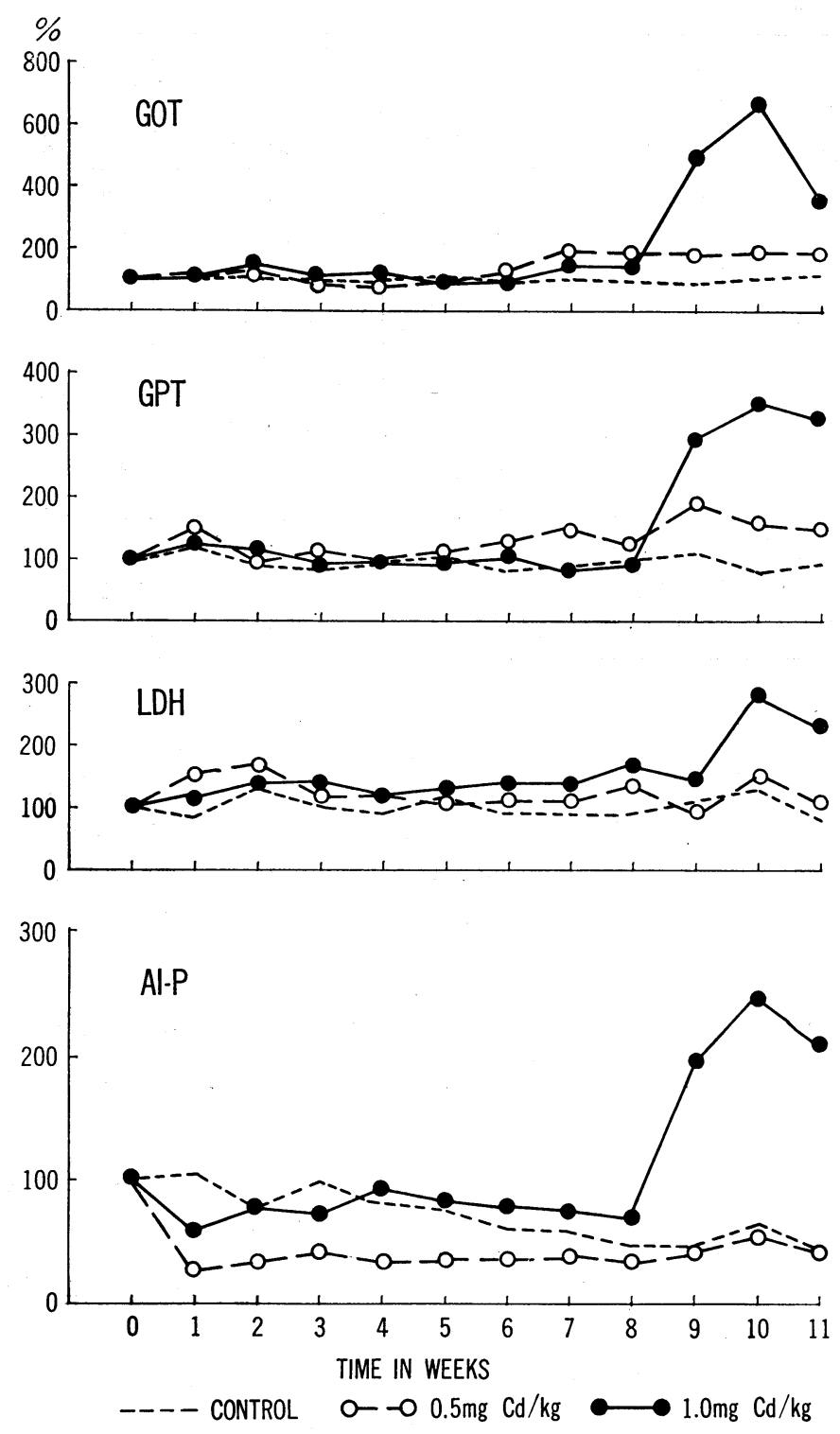

Fig. 2. Curves for GOT, GPT, LDH, and Al-P activities in plasma of rabbits injected daily with cadmium.

Free fatty acid. As shown in Fig. 3, free fatty acid in plasma increased with $\mathrm{Cd}$ injection, though not gradually following daily injection of $\mathrm{Cd}$. No significant difference was found between $\mathrm{Cd}$ injected groups and control group. The level was higher in the Group I than in the Group II.

Ca. As shown in Fig. 4, Ca level in plasma did not differ between the $\mathrm{Cd}$ injected groups and control group. 

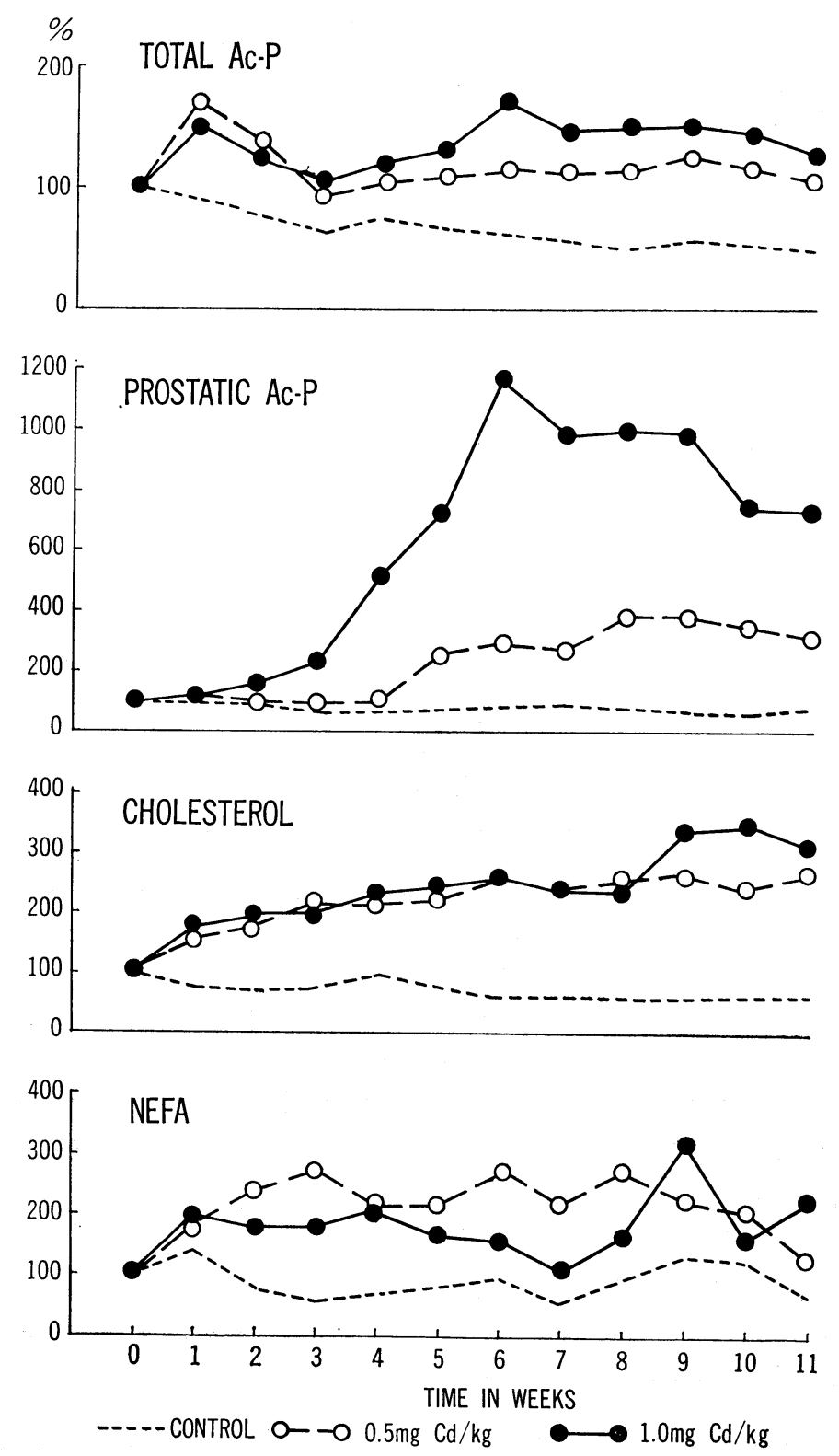

Fig. 3. Curves for total Ac-P, prostatic Ac-P, cholesterol, and NEFA in plasma of rabbits injected daily with cadmium.

$P$. As shown in Fig. 4, phosphorous level in plasma decreased by a daily injection of $\mathrm{Cd}$, but it decreased similarly in the control group.

From these results, the changes in the composition of enzymes and other constituents in plasma of rabbits administered with $\mathrm{Cd}$ could be classified into 3 groups; that is, a group that changes remarkably at an early stage of $\mathrm{Cd}$ injections as in pro- 

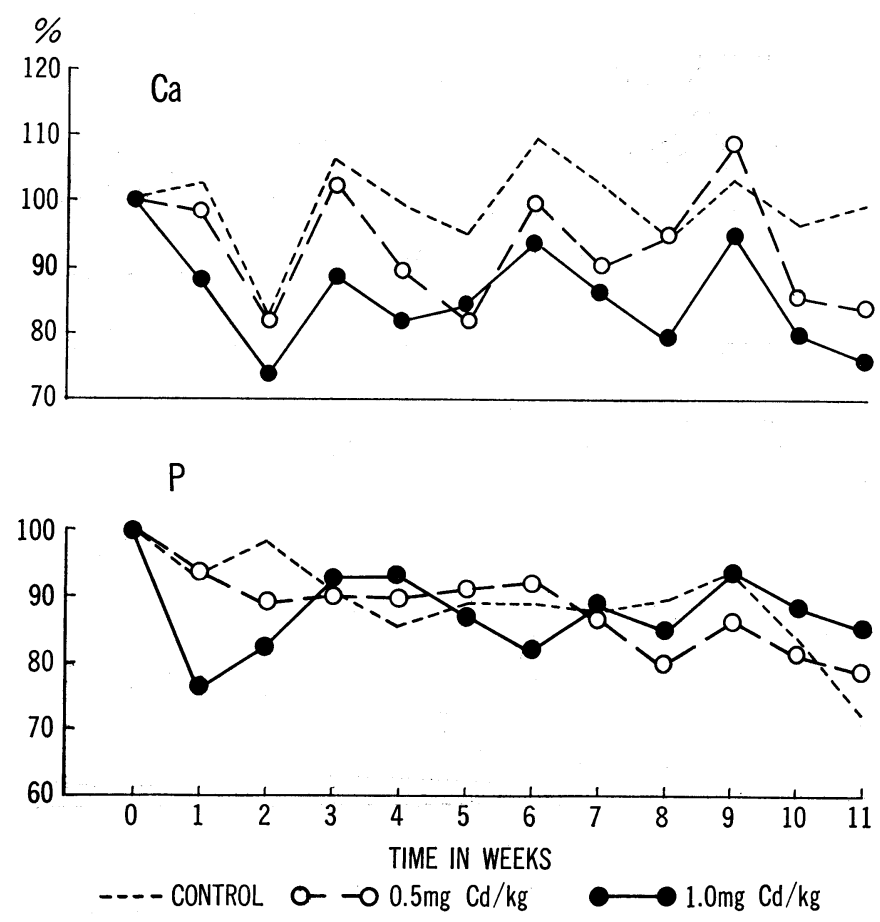

Fig. 4. Curves for calcium and phosphorous levels in plasma of rabbits injected daily with cadmium.

static Ac-P, cholesterol, and free fatty acid; a group that appears to change since the occurrence of Cd poisoning as in GOT, GPT, LDH, and Al-P; and a group that does not change by $\mathrm{Cd}$ injection as in $\mathrm{Ca}$ and $\mathrm{P}$. Since rabbits in the Group I did not suffer from $\mathrm{Cd}$ poisoning, they only showed a rise of prostatic Ac-P, cholesterol, and free fatty acid in plasma.

\section{Distribution of $\mathrm{Cd}, \mathrm{Cu}, \mathrm{Mn}$, and $\mathrm{Zn}$ among organs}

The contents of metals in blood and in organs at the end of the experiment are shown in Table 2 and Figs. 5, 6, 7 and 8.

$C d, C u$, and $Z n$ in blood. Cd content of blood in control rabbits was $4.33 \mu \mathrm{g} / 100 \mathrm{ml}$ and the concentration of $\mathrm{Cd}$ in red blood cells and plasma was the same. But in rabbits injected with $\mathrm{Cd}, 80$ to $90 \%$ of $\mathrm{Cd}$ in blood was concentrated in red blood cells. $\mathrm{Cd}$ contents of blood in rabbits injected with $1.0 \mathrm{mg} \mathrm{Cd} / \mathrm{kg}$ were 1.75 times as high as that in rabbits injected with $0.5 \mathrm{mg} \mathrm{Cd} / \mathrm{kg}$, but $\mathrm{Cd}$ contents in red blood cells were similar in both the groups while of plasma $\mathrm{Cd}$ contents in the group II were twice as high as those in the Group I.

$\mathrm{Cu}$ and $\mathrm{Zn}$ contents in red blood cells of rabbits injected with $\mathrm{Cd}$ increased while these contents in plasma did not show a difference between $\mathrm{Cd}$ injected groups and control group. 


\section{CLINICO-CHEMICAL STUDY OF CADMIUM POISONING}

$C d$ in organs. $\mathrm{Cd}$ contents in kidneys $(0.56 \pm 0.25 \mu \mathrm{g} \mathrm{Cd} / \mathrm{g}$. wet wt.), liver $(0.38 \pm 0.04$ $\mu \mathrm{g} / \mathrm{g})$ and submandibular glands $(0.32 \pm 0.23 \mu \mathrm{g} / \mathrm{g})$ from control rabbits were higher than those in other organs.

Daily injected Cd concentrated mainly in liver, kidneys and submandibular glands, and $\mathrm{Cd}$ contents in heart, lungs, spleen, adrenals and testes were small as shown in Fig. 5.

Table 2. $\mathrm{Cd}, \mathrm{Cu}$, and $\mathrm{Zn}$ contents in whole blood, red blood cells, and plasma.

\begin{tabular}{c|l|c|c|c}
\hline \multicolumn{2}{c|}{} & $\begin{array}{c}\text { Whole blood } \\
\mu \mathrm{g} / 100 \mathrm{ml}\end{array}$ & $\begin{array}{c}\text { Red blood cells } \\
\mu \mathrm{g} / 100 \mathrm{ml}\end{array}$ & $\begin{array}{c}\text { Plasma } \\
\mu \mathrm{g} / 100 \mathrm{ml}\end{array}$ \\
\hline $\mathrm{Cd}$ & Control & $4.33 \pm 0.95^{*}$ & $4.23 \pm 0.97$ & $4.45 \pm 1.99$ \\
& $0.5 \mathrm{mg} \mathrm{Cd} / \mathrm{kg}$ & $162.17 \pm 21.33$ & $730.23 \pm 228.26$ & $13.43 \pm 6.14$ \\
& $1.0 \mathrm{mg} \mathrm{Cd} / \mathrm{kg}$ & $284.43 \pm 60.24$ & $805.50 \pm 431.47$ & $29.00 \pm 6.73$ \\
$\mathrm{Cu}$ & Control & $143.48 \pm 23.92$ & $170.40 \pm 20.83$ & $120.47 \pm 29.97$ \\
& $0.5 \mathrm{mg} \mathrm{Cd} / \mathrm{kg}$ & $275.77 \pm 82.56^{* *}$ & $288.47 \pm 93.70^{* *}$ & $219.17 \pm 37.13^{* *}$ \\
& $1.0 \mathrm{mg} \mathrm{Cd} / \mathrm{kg}$ & $127.35 \pm 40.79$ & $246.27 \pm 117.36$ & $96.35 \pm 22.27$ \\
$\mathrm{Zn}$ & Control & $455.53 \pm 45 \cdot 35$ & $739.53 \pm 52.54$ & $209.43 \pm 43.77$ \\
& $0.5 \mathrm{mg} \mathrm{Cd} / \mathrm{kg}$ & $419.93 \pm 25.17$ & $1348.00 \pm 453.93^{* *}$ & $163.13 \pm 48.63$ \\
& $1.0 \mathrm{mg} \mathrm{Cd} / \mathrm{kg}$ & $361.90 \pm 127.29$ & $1208.75 \pm 360.87$ & $197.55 \pm 60.11$ \\
\hline
\end{tabular}

$*: \mathrm{x} \pm$ S.D.

**: shows the statistical significance to control value.
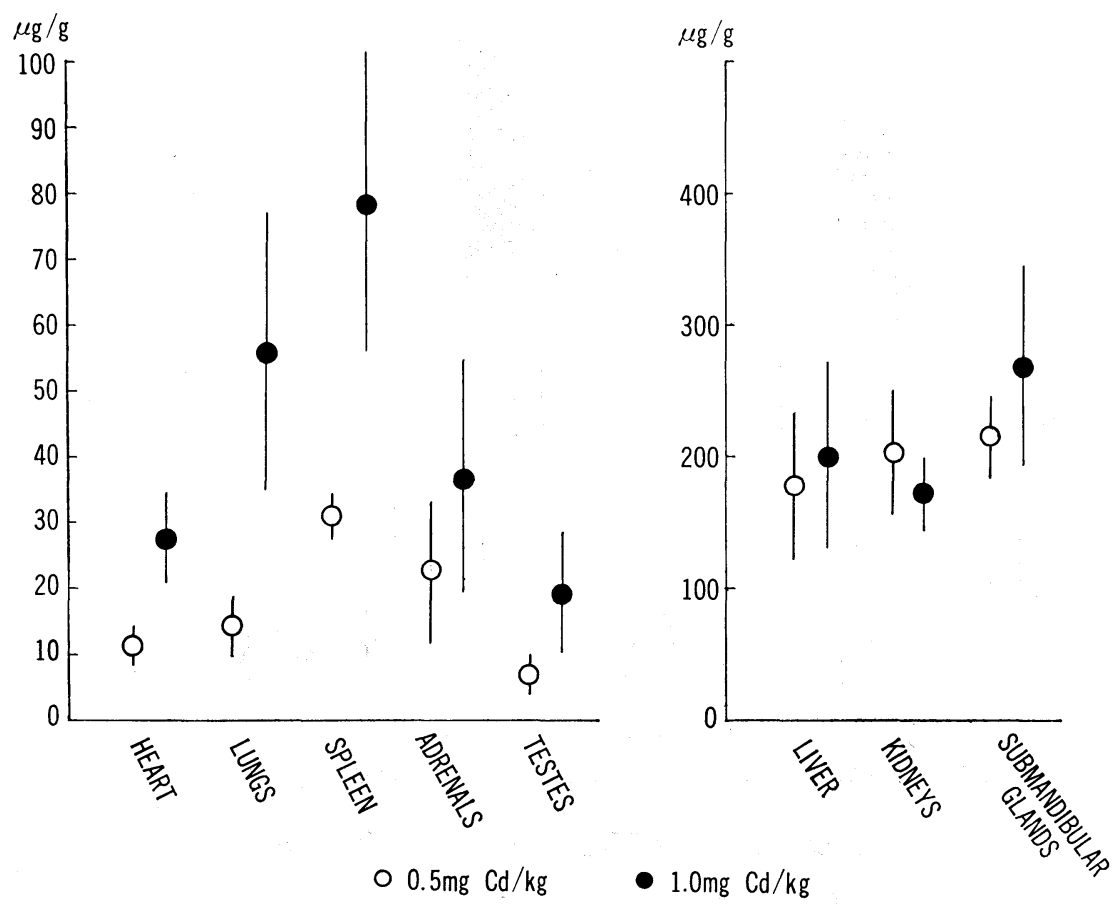

Fig. 5. Cd contents $(\mu \mathrm{g} / \mathrm{g})$ in organs. 


\section{H. YOSHIKAWA, M. OHSAWA, AND M. KANETA}

Comparing Cd contents in organs between the Group I and the Group II, liver, kidneys and submandibular glands which contained high contents of $\mathrm{Cd}$, it was not recognized to differ between the two groups. On the other hand, in heart, lungs, spleen and testes which showed a low level of $\mathrm{Cd}$ a significant difference of $\mathrm{Cd}$ contents
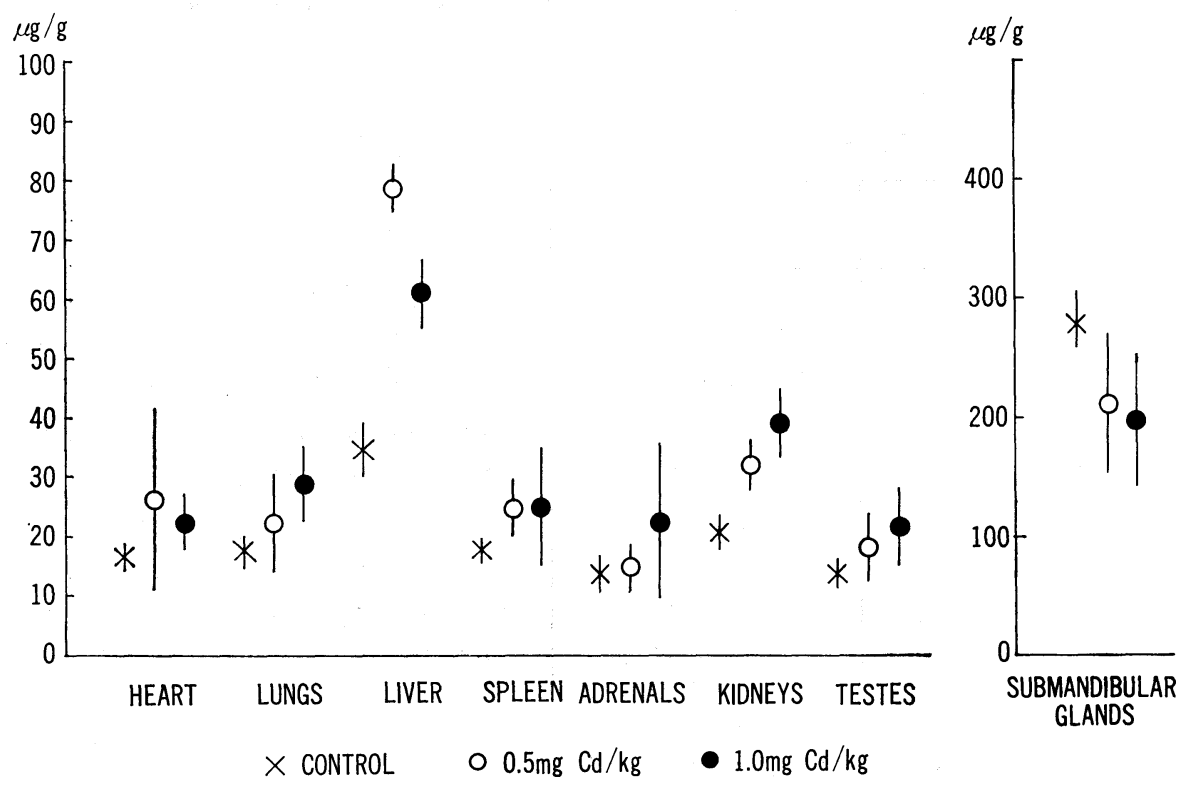

Fig. 6. $\mathrm{Zn}$ contents $(\mu \mathrm{g} / \mathrm{g})$ in organs.

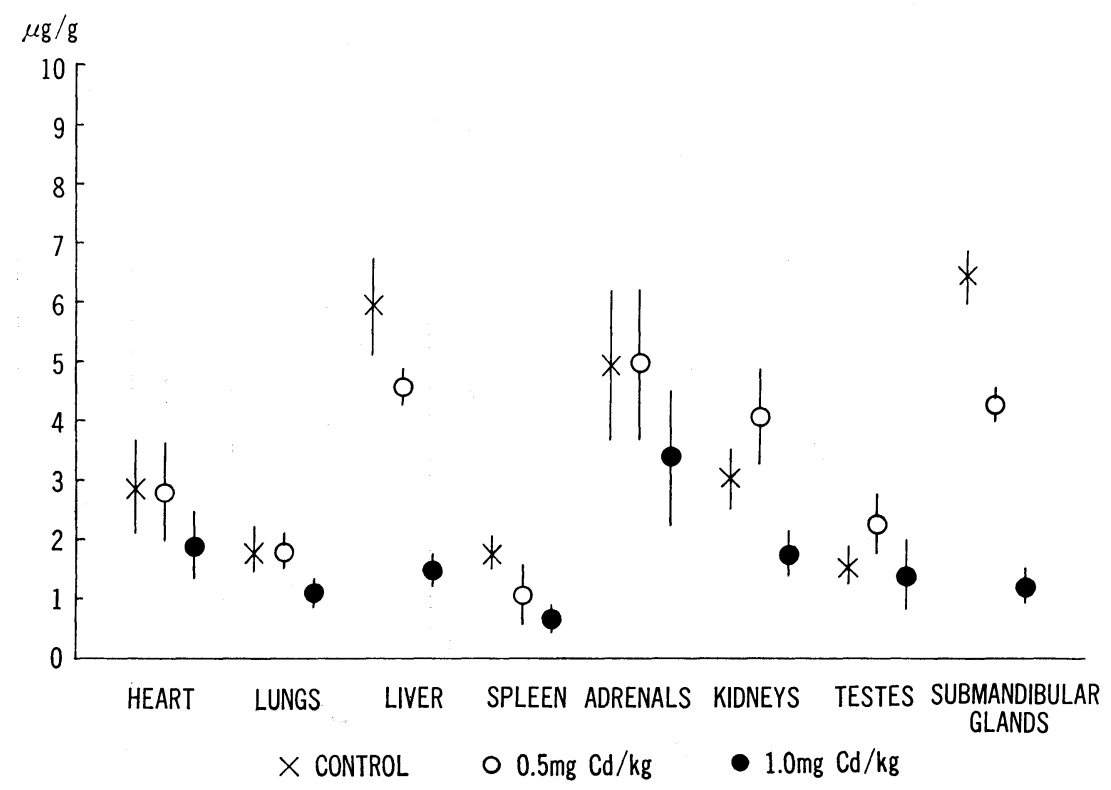

Fig. 7. $\mathrm{Cu}$ contents $(\mu \mathrm{g} / \mathrm{g})$ in organs. 


\section{CLINICO-CHEMICAL STUDY OF CADMIUM POISONING}

between the two groups was observed, that is, Cd contents in the Group II were significantly high compared with those in the Group I.

$\mathrm{Zn}$ in organs. $\mathrm{Zn}$ contents of organs in rabbits injected daily with $\mathrm{Cd}$ were shown in Fig. 6. Zn contents in organs increased except in submandibular glands, where they decreased by $\mathrm{Cd}$ injection. However, the degree of increase in $\mathrm{Zn}$ contents was similar in both the Groups of I and II.

$\mathrm{Cu}$ in organs. $\mathrm{Cu}$ contents of organs in rabbits injected daily with $\mathrm{Cd}$ were shown in Fig. 7. $\mathrm{Cu}$ contents in organs decreased generally in rabbits injected with $\mathrm{Cd}$.

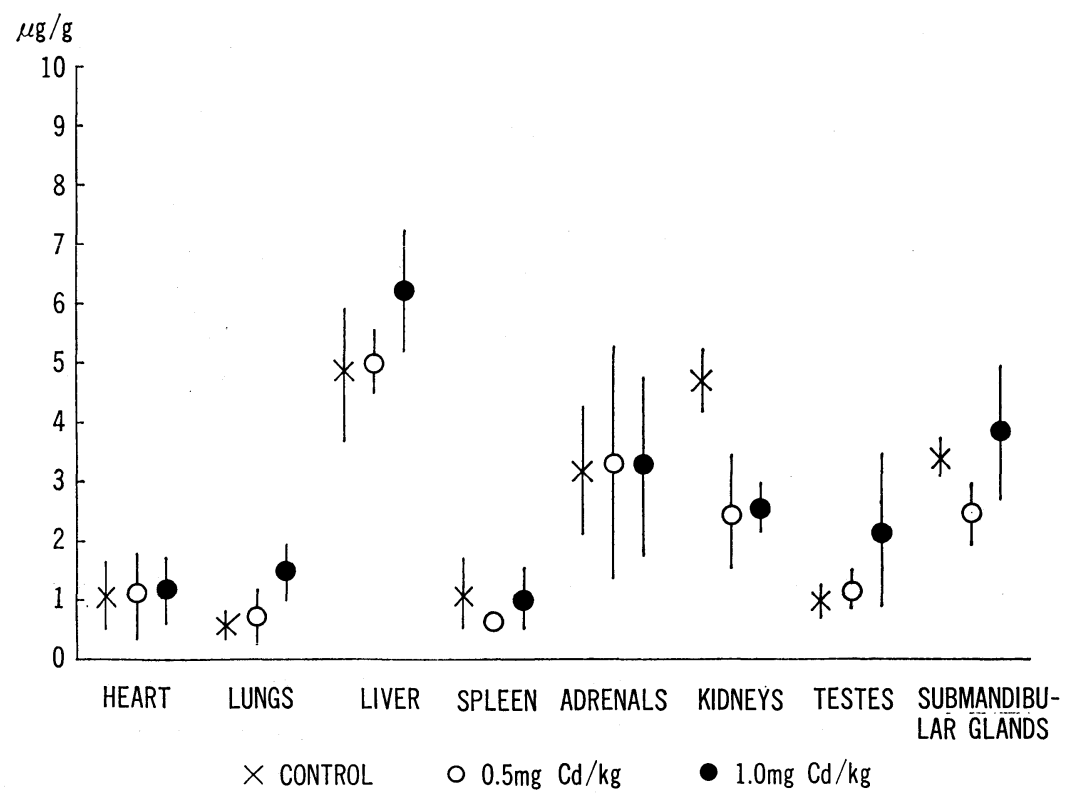

Fig. 8. Mn contents $(\mu \mathrm{g} / \mathrm{g})$ in organs.

$M n$ in organs. Mn contents of organs in rabbits injected with $\mathrm{Cd}$ were shown in Fig. 8. Mn contents of organs did not change remarkably as found in the contents of $\mathrm{Cu}$ and $\mathrm{Zn}$. A tendency to increase of $\mathrm{Mn}$ was observed in lungs, liver and testes. On the other hand, Mn in kidneys decreased significantly.

\section{Discussion}

The clinico-chemical findings appeared after the intake of $\mathrm{Cd}$ will be either the change caused by the interaction between $\mathrm{Cd}$ and some substances in the body and/or the result of damage caused by $\mathrm{Cd}$ poisoning. The authors attempted to obtain the information of early signs of $\mathrm{Cd}$ intake on some enzymes, lipils, and inorganic substances in plasma. 


\section{H. YOSHIKAWA, M. OHSAWA AND M. KANETA}

The rabbit injected daily with $0.5 \mathrm{mg} \mathrm{Cd} / \mathrm{kg}$ for 11 weeks gained the body weight after 4 weeks, though not for 3 weeks of the early stage. Accordingly, rabbits in this group might not produce the manifest $\mathrm{Cd}$ poisoning. In the Gronp II, after 8th week the body weight decreased clearly, so it might be able to estimate that these rabbits had the severe $\mathrm{Cd}$ poisoning at this time.

The activities of GOT, GPT, LDH and Al-P in plasma rose remarkably after the 8th week in the Group II. These findings will show the result of $\mathrm{Cd}$ poisoning. Much is known about an interference of many enzymes by $\mathrm{Cd},{ }^{20)}$ but there have been few reports concerning the effect on some enzymes in plasma in the experimental Cd poisoning. Cousins et al. ${ }^{21}$ ) have shown no change of Al-P in plasma on the swine orally administered with $\mathrm{Cd}$, but Piscator ${ }^{22)}$ and Hirota ${ }^{23)}$ have recognized an increase of Al-P activity in plasma in Cd poisoned rabbits. The increase of Al-P activity in plasma seems to be produced in case of the severe $\mathrm{Cd}$ poisoning according to the result of the authors.

There has been no report concerning Ac-P activity in plasma of rabbits poisoned with Cd. But the authors observed an interesting fact as above-described. This could not explain the rise of total and prostatic Ac-P activities of plasma with $\mathrm{Cd}$ administration yet, but it has been recently reported that $\mathrm{Cd}$ may take part in prostatic cancer. ${ }^{24,25)}$ So it is assumed that $\mathrm{Cd}$ has an injurious action on prostatic glands, and the rise of prostatic Ac-P activity in plasma would be able to be estimated as an early sign of excess Cd intake.

The cholesterol and free fatty acid levels in plasma increased at an early stage of $\mathrm{Cd}$ intake. Especially, cholesterol increased gradually following administration. An increase of cholesterol in plasma with Cd administration has been reported by Schroeder. ${ }^{26)}$ Though it has not been decided whether Cd has the direct action on lipid metabolism or not, it has been reported that $\mathrm{Cd}$ cause the hypertension ${ }^{10,11}$ and cardiovascular diseases. ${ }^{12,27)}$ From these findings, it would be necessary to investigate about the action of $\mathrm{Cd}$ on lipid metabolism. In any case, an increase of cholesterol and free fatty acid levels in plasma will be a sign of excess of $\mathrm{Cd}$ intake.

Kennedy ${ }^{28)}$ showed that serum $\mathrm{Ca}$ level was lowered by intravenous injection of $\mathrm{Cd}$. Hirota $^{23)}$ has recognized that serum $\mathrm{Ca}$ level rises and phosphorous level descends by $\mathrm{Cd}$ administration. The authors, however, could not find the changes of $\mathrm{Ca}$ and $\mathrm{P}$ level in plasma. This discrepancy may be due to the difference in experimental conditions. Furthermore, the effect of $\mathrm{Ca}$ and $\mathrm{P}$ caused by $\mathrm{Cd}$ administration should be discussed from both of the change in blood and in urine of $\mathrm{Ca}$ and $\mathrm{P}$.

The administered dosage of $\mathrm{Cd}$ in the Group II is about twice as high as that of the Group I. So it is reasonable that Cd contents in organs of the Group II are higher than those of the Group I. As shown in Fig. 5, however, Cd contents in liver, kidneys and submandibular glands do not different between the two groups, though $\mathrm{Cd}$ contents of heart, lungs, spleen and testes were found significantly different between the two groups. No difference of $\mathrm{Cd}$ contents in liver, kidneys, submandibular glands 


\section{CLINICO-CHEMICAL STUDY OF CADMIUM POISONING}

between the two groups can not be explained yet. Suzuki ${ }^{29)}$ and Nomiyama ${ }^{30)}$ have reported that $\mathrm{Cd}$ contents in liver decreased after an arrival at peak concentrations though $\mathrm{Cd}$ administration is contined. Cd contents in liver at the 11th week of the Group II may be correspond to this stage of decreasing while those of the Group I are increasing yet, so it may be showed accidentally that the similar Cd level in liver in both the groups be observed. Moreover, if an organ has a limited capacity for concentrating $\mathrm{Cd}$, liver and kidneys of both the groups may have arrived already their limits. However, the rabbits injected with $1.0 \mathrm{mgCd} / \mathrm{kg}$ for 11 weeks will be able to be considered as $\mathrm{Cd}$ poisoned animal from a decrease of body weight, severe weakening, and the rise of enzyme activity in plasma. An increase of GPT activity in plasma has been thought to be resulted from a liver damage. It is interesting that the liver of rabbit injected with $1.0 \mathrm{mg} \mathrm{Cd} / \mathrm{kg}$ has a damage that provoke an increase of GPT activity in plasma, although in rabbit injected with $0.5 \mathrm{mg} \mathrm{Cd} / \mathrm{kg}$, an increase of GPT activity in plasma is not recognized in spite of that the Cd contents in liver was similar in both the groups.

If $\mathrm{Cd}$ in organs is composed of the active state $\mathrm{Cd}$ as combined with functional enzymes and the inactive state $\mathrm{Cd}$ as combined with non-functional proteins, e.g., metallothionein, when the ratio of active state $\mathrm{Cd}$ to total $\mathrm{Cd}$ in liver is large, this liver might be subjected to the damage. On the contrary, when this ratio is small, the liver might be maintained healthy. If this assumption is reasonable, the degree of damage caused by $\mathrm{Cd}$ does not correspond with total amount of $\mathrm{Cd}$ in organs, that is, a doseresponse relationship could not be applied to this case.

Recently, it has been noticed that $\mathrm{Cu}$ and $\mathrm{Zn}$ contents in organs are changed by $\mathrm{Cd}$ administration. Underwood ${ }^{31)}$ has introduced many reports concerning an interaction of $\mathrm{Cu}$ and $\mathrm{Zn}$ on $\mathrm{Cd}$. The physiological meaning of this metal shift in organ has not been explained yet. However, a remarkable increase of $\mathrm{Zn}$ in most of organs will be supposed to cause a disturbance of $\mathrm{Zn}$ metabolism. Also, in $\mathrm{Cu}$, it will be able to insist similarly. $\mathrm{Cu}$ and $\mathrm{Zn}$ shifts are especially remarkable in liver and kidneys containing a large quantity of $\mathrm{Cd}$. Though this metal shift is undoubtedly a phenomenon provoked by $\mathrm{Cd}$ accumulation, this phenomenon is interesting that either the result of damage caused by $\mathrm{Cd}$ poisoning or the result of protection produced to $\mathrm{Cd}$ toxicity. Also, $\mathrm{Zn}$ contents in liver of Cd-group increase to about twice as high as and $\mathrm{Cu}$ contents decrease to about $1 / 2$ times as high as those of control in liver. It might be suggested that this remarable increase or decrease of essential metals could cause a damage of liver and kidneys by itself.

\section{REFERENCES}

1) Kazantzis, G., Flynn, F.V. and Spowage, J.S. (1963). Quart. J. Med., 32, 162.

2) Holden, H. (1965). Ann. Occup. Hyg., 8, 51.

3) Beton, D.C., Andrews, G.S., Davies, H.J., Howells, L., and Smith, G.F. (1966). Brit. J. 


\section{H. YOSHIKAWA, M. OHSAWA AND M. KANETA}

Ind. Med., 23, 292.

4) Blejer, H.P. (1966). Ind. Med. Surg., 35, 363.

5) Friberg, L. (1950). Acta Med. Scand., 138, Suppl. 240.

6) Piscator, M. (1966). Arch. Environ. Health, 12, 235.

7) Nomiyama, K. (1970). Igaku no Ayumi, 74, 249. (in Japanese)

8) Nomiyama, K. (1972). Igaku no Ayumi, 83, 121. (in Japanese)

9) Friberg, L. (1959). Arch. Ind. Health, 20, 401.

10) Schroeder, H.A. (1965). J. Chronic Dis., 18, 647.

11) Perry, H.M. and Erlanger, M. (1971). Am. J. Physiol., 220, 808.

12) Carroll, R.E. (1966). J. Am. Med. Assoc., 198, 177.

13) Reitman, S. and Frankel, S. (1957). Am. J. Clin. Pathol., 28, 56.

14) Bessey, O.A., Lowry, O.H. and Brock, M.J. (1946). J. Biol. Chem., 164, 321.

15) Cabaud, P.G. and Wroblewski, F. (1958). Am. J. Clin. Pathol., 30, 234.

16) Zak. B. (1957). Am. J. Clin. Pathol., 27, 583.

17) Novak, M. (1965). J. Lipid Res., 6, 431.

18) Connerty, H.V. and Briggs, A.R. (1965). Clin. Chem., 11, 716.

19) Taussky, H.H. and Shorr, E. (1966). J. Biol. Chem., 202, 675.

20) Vallee, B.L. and Ulmer, D.D. (1972). Ann. Rev. Biochem., 41, 91.

21) Cousins, R.J., Barber, A.K. and Trout, J.R. (1973). J. Nutr., 103, 964.

22) Axelsson, B. and Piscator, M. (1966). Arch. Environ. Health, 12, 360.

23) Hirota, M. (1971). Acta Sch. Med. Univ. Gifu, 9, 82. (in Japanese)

24) Malcolm, D. (1972). Ann. Occup. Hyg., 15, 33.

25) Potts, C.L. (1965). Ann. Occup. Hyg., 8, 55

26) Schroeder, H.A. (1968). J. Nutr., 94, 475

27) Perru, H.M. (1971). Environmental Geochemistry in Health and Disease (Edited by Cannon, H.L. and Hopps, H.C.), p. 179. The Geological Society of America, Boulder.

28) Kennedy, A. (1966). Brit. J. Ind. Med., 23, 313.

29) Suzuki, Y. (1974). Abstracts of the 47th annual meeting of Japan Association of Industrial Health. (in Japanese)

30) Nomiyama, K., Nomiyama, H., Sugata, Y. and Yamamoto, A. (1974). Jap. J. Hyg., 29, 69. (in Japanese)

31) Underwood, E.J. (1971). Trace Elements in Human and Animal Nutrition, p. 270, Academic Press, New York and London. 